NBER WORKING PAPER SERIES

\title{
HOW OFTEN ARE PROPOSITIONS ON THE EFFECTS OF CUSTOMS UNIONS THEORETICAL CURIOSA AND WHEN SHOULD THEY GUIDE POLICY?
}

\author{
Lisandro Abrego \\ Raymond Riezman \\ John Whalley
}

Working Paper 8304

http://www.nber.org/papers/w8304

\author{
NATIONAL BUREAU OF ECONOMIC RESEARCH \\ 1050 Massachusetts Avenue \\ Cambridge, MA 02138 \\ May 2001
}

We are grateful to the Centre for the Study of Globalisation and Regionalisation at the University of Warwick and the ESRC for financial support. We acknowledge comments at Centre seminars. Scott Page, Carlo Perroni, Chuck Whiteman and Ben Zissimos have also provided helpful input. An earlier version was presented to a conference on the WTO and World Trade held in Seattle, December 4, 1999 and the Ecole de Printemps held in Aix-enProvence, May 2000. We thank participants in these conferences for useful comments. The views expressed herein are those of the authors and not necessarily those of the National Bureau of Economic Research.

(C) 2001 by Lisandro Abrego, Raymond Riezman and John Whalley. All rights reserved. Short sections of text, not to exceed two paragraphs, may be quoted without explicit permission provided that full credit, including $\odot$ notice, is given to the source. 
How Often are Propositions on the Effects of Customs Unions Theoretical

Curiosa and When Should They Guide Policy?

Lisandro Abrego, Raymond Riezman and John Whalley

NBER Working Paper No. 8304

May 2001

JEL No. F10, F13, F15

\section{$\underline{\text { ABSTRACT }}$}

This paper uses computational techniques to assess whether or not various propositions that have been advanced as plausible in the literature on Customs Unions (or other regional trade agreements) may actually hold. The idea is to make probabilistic statements as to whether propositions of interest might hold, rather than to restrict assumptions so they unambiguously hold. Our aim is to blend theory and numerical simulation and go beyond the ambiguous analytically derived propositions that dominate the theoretical literature so as to assess the likelihood of propositions holding for particular model specifications.

Lisandro Abrego

University of Warwick
Raymond Riezman

University of Iowa
John Whalley

Universities of Warwick and Western Ontario

and NBER 


\section{INTRODUCTION}

In this paper, we generate repeated model solutions for alternative numerical specifications of a simple (few countries and commodities) general equilibrium trade model so as to map out the extent of the parameter space for which each of a series of propositions regarding customs unions is true ${ }^{1}$. The idea is to blend theory and numerical simulation, in contrast to theoretical work in this area which sets out assumptions under which propositions unambiguously hold, and demonstrates their validity using analytical techniques. Here we take a different approach of trying to determine the frequency with which various results hold so as to obtain an indication of which statements are more likely to hold and which not.

We apply the techniques we develop to the analysis of various propositions in the customs union literature because despite nearly fifty years of research, which originates with Viner's (1950) work no set of generally accepted propositions regarding their effects has yet emerged to guide policy makers and public officials. Whether individual countries necessarily gain by entering a customs union (CU) is unproven, and the use of alternative reference points, such as free trade or non-cooperative Nash, only further clouds the picture. Whether world welfare is higher under a $\mathrm{CU}$ is also unknown, as is whether customs unions generate higher external tariffs compared to a non-cooperative Nash equilibrium in tariffs. Other propositions are widely thought to be true, but without explicit confirmation; such as that CUs generally improve the terms of trade of member countries; and that non-member countries prefer that no customs union be formed against them.

Specifically, we consider a three-country, three-good, pure exchange model with CES preferences, and use both random draws and a grid search over the space defining preference parameters and endowments. We compare both free trade and three-country non-cooperative (Nash) equilibria to partial cooperation regional agreement equilibria where two countries form a regional agreement and play non-cooperatively against the third country (CU). If we assume a uniform prior over the parameter space(admittedly a strong assumption) and then calculate the

\footnotetext{
${ }^{1}$ This differs from previous work on systcmatic scnsitivity analysis for goneral cquilibrium models due to Pagan and Shannon (1986) and Harrison and Wigie (1992) which focuses on the sensitivity of counterfactual equilibrium results to key parameters, such as elasticities, in calibrated models for which parameter estimates are scarce. Sample frequencies for propositions are our objective more so than sensitivity analysis of central case results. In the process we compute non-coopcrative game thcorctic solutions as well as coopcrative solutions for draws from the cntire parameter space and we also go beyond cxisting literature in this dimcnsion.
} 
percentage of cases for which certain results hold, our sample frequencies can be interpreted as the probability of particular propositions holding conditional on both the model and the assumed prior.

Taken as a set, our results show that numerical simulation can be an important and useful adjunct to theory in economics. None of the propositions we consider holds unambiguously; some hold over $80 \%$ of the time, others considerably less frequently. We also investigate the reasons why particular propositions seem to hold more frequently than others using additional model analyses. Thus, where theory does not yield clear and unambiguous results, numerical simulation can be used to generate insights as to the likelihood of and reasons for particular propositions holding and we believe, yield significant benefits in many other areas.

\section{CUSTOMS UNION LITERATURE AND THEORY-SIMULATION INTERACTIONS}

Because of our focus on ambiguous propositions in the customs union literature, prior to presenting our analyses it is helpful to provide some background. Ambiguity in theoretical outcomes has been a constant in this literature since its inception. In 1950 Jacob Viner, the initiator for subsequent customs union literature, pointed out that such agreements do not necessarily result in gains to members, even though some tariffs are eliminated by the agreement. He developed what later became known as the trade creation-trade diversion approach to customs union agreements to help understand this ambiguity. Following Viner's work, for many years trade creating regional agreements were seen as good, and trade diverting regional agreements were seen as $\mathrm{bad}^{2}$.

Viner's work was also the driving force behind later literature that subsequently sought to set out the conditions under which regional trade agreements would either improve or worsen welfare. This work was still based on trade

\footnotetext{
${ }^{2}$ These two forces can be explained with a simple example. Suppose countries A and B form a customs union while country $\mathrm{C}$ remains outside the agreement. If we suppose that before the agreement country $A$ imports clothing from country $C$, a low cost producer of clothing; and that as a result of the agreement, $A$ imports clothing instead from $B$ because $B$ had the advantage of tariff-free access to A's market, trade into $A$ is diverted from low cost producer $C$ to high cost producer B and welfare may be lowered. However, if $\mathrm{A}$ formed a union with $\mathrm{C}, \mathrm{A}$ would import more from low cost producer $C$ and less from high cost producer $B$; trade would be created and welfare increased.
} 
creation-trade diversion considerations; but Meade (1955), Lipsey (1957) and others discovered that preference considerations also enter in trying to make such determinations; this was to lead to Lipsey and Lancaster's (1958) characterization of the general theory of the second best; confirmation that no general customs union results were possible with the existing approach. Dissatisfaction with the trade creation-trade diversion dichotomy when evaluating customs union agreements eventually resulted in Lipsey (1970), Kemp (1969), Riezman (1979) and others ${ }^{3}$ trying to develop other approaches that would yield clear propositions. A new approach known as the terms of trade-volume of trade approach became popular, under which the impact of a regional trade agreement can be summarized by its effects on both terms of trade (prices) and trade volumes. This terms of trade-volume of trade approach uses general equilibrium instead of Vinerian partial equilibrium analysis, and emphasizes the impacts of the union on individual countries as integration occurs, instead of on world welfare.

However, even with the adoption of a new approach the same lack of general results has continued to characterize the literature. Indeed, few if any propositions are true for all parameter values even in highly simplified models. Consider the conjecture: "In a 3-country pure exchange economy, any pair of countries can benefit by forming a customs union agreement". In a world where countries are of the same size this conjecture is true, but as Riezman (1999) shows, this conjecture fails to hold more generally. In a world with one large and two smaller countries, a customs union agreement between the large country and either smaller country can result in the large country doing worse than in the initial equilibrium. In the initial equilibrium the large country benefits from its use of tariffs against both countries, while small countries lose. When the large country forms a customs union it shares some of its tariff advantages with the other union partner, but foregoes the opportunity to play strategically against the small partner. Thus, even in a very simple model there are still no general results even for a more restricted set of questions ${ }^{4}$.

In other literature, such as Kennan and Riezman (1990), strategic considerations underlying the formation of regional trade agreements have served to further cloud the picture. Thus, one objective behind the formation of the EU in the

\footnotetext{
${ }^{3}$ See Lloyd (1982), Wooton (1986), Riezman (1985), Kowalczyk (1989), Kemp and Wan (1976).

${ }^{1}$ There has nonetheless been intense recent policy debate over whether or not regional trade agreements are desirable in which strong positions are advanced (Bhagwati and Panagariya (1996), Summers (1991), Riezman (1999))
} 
late-50s was to enhance joint country bargaining in the GATT with the US; and Mercosur was, in part, an attempt by four countries (Brazil, Argentina, Uruguay, Paraguay) to strengthen their bargaining position for an eventual accession negotiation with NAFTA. Such considerations naturally suggest treating countries as strategic players in a multi-country mixed cooperative - non-cooperative trade policy game, but such considerations have made the search for clear propositions as to the effects customs unions even more difficult.

This paper begins then from the ambiguity of most, if not all, theoretical propositions as to what happens when regional trade agreements form. Whether individual countries benefit, whether trade volumes expand, whether tariffs rise globally are all uncertain. Such propositions are further complicated by whether a regional agreement is to be compared to free trade or a multi-country Nash outcome. Our approach is to build on the applied general equilibrium modelling literature and use numerical simulation methods to investigate the frequency with which various propositions hold. Since Miller and Spencer (1971), Shoven and Whalley (1974) and Whalley (1985), researchers have used numerical equilibrium models to simulate the effects of regional trade and customs union agreements as well as to address a range of policy questions. They were used extensively in the WTO Uruguay Round process (see Harrison, Rutherford and Tarr, (1996), and Francois, Nordstrom and McDonald, (1996)) as well as in the earlier Tokyo Round. They have also been used to explicitly model the effects of regional trade agreements (Hamilton and Whalley, (1985), Perroni and Whalley, (2000)). These models are richer (more countries, production, more commodities) than the trade models that theorists frequently use. However, general results are not obtained and propositions of the form we investigate here are not explored.

Our blend of theory and numerical simulation seeks to assess whether propositions hold most of the time, and thus stand as reasonable working hypotheses; or whether they hold seldom, and are thus largely theoretical curiosa. We do this by using numerical simulation techniques to compute equilibria for a large number of model parameterizations, and then to assess the likelihood of a given proposition holding generally by computing sample frequencies. 


\section{IMPLEMENTING PROPOSITIONAL ANALYSIS}

The literature on customs unions has focused on the effects of the formation of customs unions on the welfare of individual countries, as well as on the world as a whole. In addition, there has been work on the effects of customs union formation on the terms of trade and volume of trade of both member and non-member countries. Understanding how customs union formation affects country terms of trade and their volume of trade helps in understanding the welfare effects of customs union. Older literature concentrates on comparing customs unions to an exogenously given initial equilibrium. More recent literature ${ }^{5}$ endogenizes the initial equilibrium and also compares customs union equilibria to free trade. We follow more recent literature and focus on comparisons of customs union equilibria with three-country Nash equilibria and free trade. For each of these three equilibria we compare welfare, terms of trade and volume of trade. We assume countries 1 and 2 in a 3 -country world are the union members. We do not consider the added complication of endogenous membership of the union (see footnote 9).

We consider eight propositions as to the effects of regional trade agreements that we feel reflect central themes that the theoretical literature in the area has explored. They are widely discussed in the previously cited literature, are of theoretical interest, and have important policy implications. These are that:

1. Both members benefit from a customs union relative to free trade

2. Both members benefit from a customs union relative to a Nash equilibrium

3. A customs union increases world welfare relative to a 3-country Nash equilibrium

4. Customs unions are a "stepping stone" to free trade (i.e. members are better off in CU relative to Nash, and members gain from free trade)

5. A customs union results in higher external tariffs for member countries relative to a Nash equilibrium

6. A customs union improves member countries' terms of trade relative to a Nash equilibrium

\footnotetext{
"See Kennan and Riezman (1990) and Krugman (1991), for example
} 
7. A customs union increases member countries' volume of trade relative to free trade

8. A customs union increases member countries' volume of trade relative to a Nash equilibrium

We assess the likelihood that each of these propositions hold in a particular case; a 3 country pure exchange model based on Kennan and Riezman (1990) and specify functional forms and admissible ranges of parameter values. We consider both random parameterizations of the model drawn from the admissible parameter space and parameterizations represented by a lattice of grid points in the parameter space. For each parameterization, we compute equilibria in the presence of regional trade agreements, as well as three-country non-cooperative Nash equilibria, and free trade equilibria ${ }^{6}$. From these computed equilibria we calculate the impacts on world welfare, individual country welfare, ${ }^{7}$ prices, tariff levels, and trade volumes as regional agreements form, and hence assess whether each of the propositions holds for that parameterization.

\subsection{Model Structure}

Each country has a single representative consumer with endowments of three goods, and a utility function of the form

$$
U^{i}=U^{i}\left(X_{1}^{i}, X_{2}^{i}, X_{3}^{i}\right) \quad(i=1, \ldots, 3)
$$

where $X_{1}^{i}, X_{2}^{i}, X_{3}^{i}$ represent consumption of goods 1,2 and 3 in country $i$ and $U^{i}$ is country $i$ 's utility. Endowments are given by $\bar{E}_{1}^{i}, \bar{E}_{2}^{i}, \bar{E}_{3}^{i}$, where $i$ denotes the country, and 1, 2 and 3 denote the goods.

Because each country can impose non-negative tariffs at rate $t_{j}^{i}$ on good $j$ imported by country $i$, for any good $j$ we define the sellers prices (i.e. net of tariff prices) as $P_{j}$ for any good $j$. This implies that internal (gross of tariff) prices in any country are

$$
P_{j}^{i}=\left(1+t_{j}^{i}\right) P_{j}
$$

\footnotetext{
${ }^{6}$ We assume uniqueness of these equilibria, and have done various ad hoc tests (changing the speed of approach and the initial starting point) to search for multiple equilibria. None have been found, although Kehoe's (1980) discussion suggests that, for competitive equilibria, even in small dimensional examples multiple equilibria can occur.

${ }^{7}$ We use Hicksian equivalent moncy metric mcasures by country which we aggregate as necessary across countries for this purpase.
} 
Tariffs are set to zero on any good exported by country $i$. Countries (or regions) set optimal tariffs on all imported goods. Tariff revenues collected by country $i$ are

$$
T^{i}=\sum_{j=1}^{3} t_{j}^{i} P_{j} \max \left\{\left(X_{j}^{i}-\bar{E}_{j}^{i}\right), 0\right\}
$$

The income of country $i$ is thus given by

$$
I^{i}=\sum_{j=1}^{3} P \bar{E}_{j}^{i}+T^{i}
$$

It is easily shown that (2), (3) and (4) imply that the balance of trade for each country is zero.

We use constant elasticity of substitution (CES) (and in special cases CobbDouglas) preferences to represent the utility functions (1), for which (in the CES case) utility maximizing demands are given by

$$
X_{j}^{i}=\frac{a_{j}^{i} I}{\left(P_{j}^{i}\right)^{\sigma_{i}} \sum_{j=1}^{3} \alpha_{j}^{i} P_{j}^{i\left(1-\sigma_{i}\right)}}
$$

Where the $\alpha_{j}^{i}$ are CES preference shares on good $j$ in country $i$, and $\sigma_{i}$ are country $i$ CES substitution elasticities in preferences. Equation (2) presumes knowledge of the direction of trade for any country in any commodity. In the theoretical literature this is assumed to be given and unchanging as we move between alternative equilibria (free trade; three-country Nash; with regional trade agreements). In the model we use, the direction of trade is endogenously determined as part of the equilibrium solution. This endogeneity of trade patterns is an important feature of this model and differentiates it from previous work in this area. We achieve endogeneity by performing sequential equilibrium calculations in which the direction of trade is given by the previous iteration and then checked for consistency with the resulting model solution ${ }^{8}$. Only when full consistency is achieved do we accept this as a bonafide equilibrium solution. We find that changes in the direction of trade across equilibria occur surprisingly frequently (see Abrego, Riezman and Whalley, 2000), calling into question the use of this assumption in theoretical work.

\footnotetext{
${ }^{8}$ Initially, we use the base case trade pattern.
} 


\subsubsection{Equilibrium Solution Concepts}

We examine a range of solution concepts for our model, each relevant to the propositions listed above whose frequency we analyze. We denote demands for commodities in country $i$ by $x_{j}^{i}$, which in turn depend on prices for goods in the country and country incomes. Purchase prices within countries are sellers (world) prices gross of tariffs; i.e. $P_{j}^{i}=P_{j}\left(1+t_{j}^{i}\right)$. In the presence of tariffs, country incomes include tariff revenues.

Competitive Free Trade Equilibria In free trade, tariff rates are all zero on all products in all countries, and equilibrium prices clear markets globally, i.e. equilibrium prices $\left(P_{1}^{*}, F_{2}^{*}, F_{3}^{*}\right)$ are determined such that

$$
\sum_{j=1}^{3} X_{j}^{i}-\sum_{j=1}^{3} \bar{E}_{j}^{i}=0
$$

and global excess demands are all zero for all three commodities. Given that only relative prices matter in such a structure; we can normalize prices to sum to unity i.e.

$$
\sum_{j=1}^{3} P_{j}=1 ; \quad P_{j} \geq 0 .
$$

Three-Country Non-Cooperative Nash Equilibria We also compute 3country non-cooperative Nash equilibria. In these, each country takes other countries' tariffs as given and computes their own optimal tariffs by commodity. In equilibrium country computations of optimal tariffs are mutually consistent. The $t_{j}^{i}$ are thus endogenously determined for country $i$.

Specifically, each country determines their own optimal tariff vector $\left(t_{j}^{i}\right)^{*}$ by maximizing $U^{i}$ subject to the constraint that their balance of trade equals zero. Equilibrium occurs where global markets clear and each country charges optimal tariffs given the tariffs of other countries. Tariff revenues, $T^{i}$, enter this version of the model, and affect demands since they are redistributed to the country's representative consumer in lump sum fashion.

In equilibrium, consistent optimizing behavior on tariffs by country, market clearing and government budget balance in cach country define cquilibria. Thus each country $i$ solves an optimization problem

$$
\max U^{i}
$$


subject to

$$
\sum_{j=1}^{3} P_{j}\left(X_{j}^{i}-\bar{E}_{j}^{i}\right)=0
$$

In the problem (8), $t_{j}^{i}$ for $j \neq i$ are taken as given and denoted by $\widehat{t}_{j}^{i}$. In a Nash equilibrium, optimal tariff rates $t_{j}^{i *}=\widehat{t}_{j}^{i}$ for all $i, j$ and markets clear, i.e.

$$
\sum_{j=1}^{3} X_{j}^{i}-\sum_{j=1}^{3} \bar{E}_{j}^{i}=0 \quad \forall i
$$

Customs Union Equilibria We also compute customs union equilibria for this model. In these, we assume that country 1 and country 2 form a customs union with zero tariffs between them, and set a common external tariff against country $3^{9}$. Thus, countries 1 and 2 jointly set an optimal tariff against country 3 , and country 3 sets an optimal tariff against the other two countries. Members of the Union receive the tariff revenues collected on their own imports.

In this mixed cooperative, non-cooperative case, countries 1 and 2 set zero tariffs against each other, i.e. $t_{j}^{1}=t_{j}^{2}=0$ if the supplying country is 1 or 2 , but jointly set optimal tariffs against country 3 . Since countries 1 and 2 typically have a conflict of interest over how their joint external tariff is set, we assume that this tariff is set to maximize the sum of country 1 and 2's utilities. We then use different weights on country utilities in this joint sum in subsequent sensitivity analyses.

The customs union optimization problem is given by

$$
\max U^{1}+U^{2}
$$

subject to

$$
\sum_{i=1}^{2} \sum_{j=1}^{3} P_{j}\left(X_{j}^{i}-\bar{E}_{j}^{i}\right)=0
$$

In this case, the computation of tariff revenues requires that bilateral trade flows be accounted for in the model, unlike for free trade and Nash. We do this

\footnotetext{
${ }^{9}$ We have not considered cases where customs unions are themselves endogenously determined, in part because under standard cooperative game solution concepts, such as the core, no solution may exist. Hore, countrics 1 and 2 arc exogcnously chosen as the countrics which to form a union.
} 
by taking bilateral flows in any good to be given by the difference in the sum of country 1 and 2 imports of good $j$ and the exports of good $j$ by country 3 . Such a calculation is only necessary for the goods that country 3 exports, and the direction of trade in such goods at any point in model calculations is given by the directional assumption in force at that point.

\subsection{Implementing the Approach}

To compute sample frequencies for the propositions we list above holding, we use two different procedures for generating alternative model parameterizations.. One is a randomization which, in our central case analysis, we implement across both preference parameters (both shares and elasticities) and endowments. In this we consider CES preferences and generate share and substitution parameters in preferences for all three countries as well as endowments normalized to lie in a unit interval for each good for each country. The other uses a search over a grid defined only on endowment configurations since the dimensionality of the grid becomes unworkably large if we also include preference parameters.

The reason for using these two methods is to both check that they yield comparable results, and to provide a better understanding of the factors underlying computed sample frequencies. Since our central case involves randomizing over both preference parameters and endowments, for comparability to our grid search in which we only consider endowment configurations we later analyze randomizations restricted to endowment configurations only. In our grid search, we focus on the case where share parameters are identically symmetric across countries (all one third), and substitution elasticity values are common to all countries. We search across equilibria associated with parametric specifications of the model given by a lattice grid of points in the parameter space. In these cases we first restrict ourselves to Cobb-Douglas preference functions, and later do CES sensitivity analysis with different preference share parameters across goods and use varying elasticities of substitution.

Table 1 sets out the key features of the procedures we use in computing equilibria on which our sample frequencies are based. Table 2 sets out in more detail an example of the parametric variations we make over the endowment parameter space in the grid search cases we have constructed. We assume that the global endowment of each good is 1 by choice of units, and consider own country endowments of goods that range between .1 and .9. We consider off diagonal elements of the endowment array to be symmetric. Table 2 indicates a case of $(0.1,0.3$, 
0.4) translates into the endowment array by good by country given in Table 2. 
Table 1

Key Features of the Procedures Used in Propositional Analysis in the Central Case

$\begin{array}{ll}\text { Dimensionality: } & 3 \text { countries, } 3 \text { goods } \\ \text { Preferences: } & \text { Randomization : CES } \\ & \text { Grid search : Cobb-Douglas - symmetric } \\ & \text { identical preferences across countries, with } \\ & \text { shares equal to } 1 / 3 \text { for each good } \\ \text { Endowments: } & \text { Randomization : Randomly drawn from } \\ & \text { the intterval 0.05-1.0 for each good for each } \\ & \text { country } \\ & \text { Grid search : Lattice grid of model spec- } \\ & \text { ifications, with country endowment inter- } \\ & \text { vals for each good of 1, 1 for each country. } \\ & \text { Off diagonal elements are treated as sym- } \\ & \text { metric. Thus, each model specification is } \\ & \text { given by a 3-dimensional vector (see below) } \\ & \text { from a range of endowments is generated. } \\ & \text { Randomization : We consider 2000 draws } \\ \text { Number of cases: } & \text { from the range of potential parametric } \\ & \text { specifications } \\ & \text { Grid search : We consider } 769 \text { different } \\ & \text { model specifications reflecting a single in- } \\ & \text { teger grid in own endowments } \\ \text { Equilibria } & \text { Competitive equilibria, three-country } \\ \text { for each case for each } & \text { Nash equilibria, Customs Union equi- } \\ \text { method } & \text { libria (the sum of member utilities is } \\ & \text { maximized). }\end{array}$




\section{Table 2}

\section{An Example of a Model Parametric Specification Generated by the Grid Search Procedure}

\begin{tabular}{cccc} 
Endowment of Goods & \multicolumn{4}{c}{ Country } \\
& 1 & 2 & 3 \\
1 & 0.10 & 0.35 & 0.30 \\
2 & 0.45 & 0.30 & 0.30 \\
3 & 0.45 & 0.35 & 0.40
\end{tabular}

The grid search procedure we consider involves all possible own endowment configurations across the three countries with single digit decimals; a total of 769 cases. Cases which by construction are symmetric are excluded (e.g. $(0.2,0.4,0.6)$ gives the same equilibrium solution as $(0.4,0.2,0.6)$ ). In randomization cases we limit our parametric specification to the relevant range for each parameter, e.g. 0.1 for share parameters. We consider 2000 draws in our central case analysis. For all the specifications generated by both methods we compute free trade, threecountry Nash, and customs union equilibria and compare across these to assess sample frequencies as to how often the propositions we list above hold in the cases we consider. Assuming a uniform prior, we can interpret the computed sample frequencies in probabilistic form as the likelihood of whether or not any particular proposition holds. As noted above, an important difference between the randomization and grid search procedures is that the grid search is limited to endowments, while the randomization is over all model parameters.

In three-country Nash cases, we encounter difficulties in computing equilibria reflecting a lack of monotonicity in the individual country utilities when they are maximized with respect to their own tariff vector. Such problems are confined to the three-country Nash cases (and occur in between 17 and $20 \%$ of cases in our central case) and do not arise with customs union equilibrium computations. These problems are absent in two-country Nash computation. These problems manifest themselves in points on reaction functions being unable to be simply solved for, since the GAMS optimization code we use cycles between local equilibria. These problems are more common in cases where trade directions change, 
but occur where there are no directional changes and are absent for some trade direction change cases.

\section{RESULTS}

\subsection{Central Case results}

Table 3 presents results for the central case in which all model parameters (preferences and endowments) are randomized. In these, we randomly draw preference (share and elasticity) parameters and endowment configurations for 2000 cases, and for each compute free trade, customs union, and Nash equilibria. We compile sample frequencies for the eight propositions holding that we list on page 5 .

Results in Table 3 indicate that some propositions hold in a clear majority of computed cases (proposition 7, whether a CU improves the members' terms of trade relative to Nash) while others hold less frequently. For instance, both members benefit by forming a customs union relative to the three-country Nash outcome in only $48 \%$ of the cases. A customs union improves world welfare relative to a Nash equilibrium in $76 \%$ of computed cases. Customs unions result in higher external tariffs for member countries compared to Nash in $72 \%$ of cases. Customs unions lead to more international trade for member countries (relative to Nash) $87 \%$ of the time. At the other end of the spectrum only in $4 \%$ of the cases are customs unions a "stepping stone" to free trade. We next discuss each of the results in more detail.

Propositions 1 and 2 look at welfare changes between equilibria. Proposition 1 suggests that both members of a customs union do better than at free trade in about $20 \%$ of the cases while that number jumps to almost $50 \%$ (Proposition 2) when the comparison is made to Nash equilibrium rather than free trade. Moving from a Nash equilibrium (or free trade) to a customs union improves the union member's bargaining power and the members should gain vis-a-vis the nonmember. From Johnson (1953) and Kennan and Riezman (1988) we know that only where there are significant asymmetries of size in a two-country case will a country gain in Nash equilibrium relative to free trade. The same logic applies to the union-non-union distinction and in our computations both members gain (i.e. the customs union is big enough) about $20 \%$ of the time.

To see the intuition for these results it helps to decompose the change into a terms of trade effect and a volume of trade effect. Moving to a customs union from either free trade or a Nash equilibrium will usually improve the terms of 
trade of union members with respect to the rest of the world (see Proposition 6.) However, within the customs union one country will see its terms of trade improve at the expense of the other member. So, for one member the terms of trade improve with respect to all trading partners while for the other the change in overall terms of trade is ambiguous and will depend on what percentage of its trade is within the customs union. The volume of trade will usually fall moving from free trade to customs union (Proposition 7) and increase moving from Nash equilibrium to customs union (Proposition 8.) Putting these effects together it follows that welfare gain for both members of a customs union is more likely when the comparison is to Nash equilibrium rather than a customs union.

The fundamental significance of Proposition 1 lies in the fact that it gives a measure of the stability of free trade. If free trade existed, more than $20 \%$ of the time there would be a customs union that would benefit both member countries. In those cases, free trade would not be very stable in the sense that there would be a tendency to defect and form a customs union. Proposition 2 implies that about half the time in a tariff ridden world there will be at least one pair of countries that can benefit from forming a customs union. Hence, in this situation there would be a strong tendency to move towards regionalism. 
Table 3

Central Case analyses of Customs Unions Propositions under Randomization over both Preference Parameters and Endowments

Proposition

1. Both members benefit from a customs union relative to free trade

2. Both members benefit from a customs union relative to a Nash equilibrium

3. Customs union increases world welfare relative to a 3-country Nash equilibrium

4. Customs unions are a "stepping stone" to free trade (i.e. members are better off in CU relative to Nash, and members gain from free trade)

5. Customs union results in higher external tariffs for member countries relative to a Nash equilibrium

6. Customs union improves member countries' terms of trade relative to a Nash equilibrium

7. Customs union increases member countries' volume of trade relative to free trade

8. Customs union increases member countries' volume of trade relative to Nash equilibrium
Sample Frequencies of computed model parameterizations for which the proposition is true

22.9

47.6

76.0

72.2

88.6

86.9 
The world welfare results for proposition 3 suggest a bias in favor of customs unions over three-country Nash equilibria when one looks at world welfare. Theoretically, here we are comparing two distorted equilibria, and moving from a Nash equilibrium to a customs union gives some tariff reduction. However, members of the customs union coordinate their external tariffs which leads to higher protection. The results therefore indicate that from a global point of view the benefits of tariff reduction outweigh the costs of tariff coordination, with a sample frequency of considerably more than half.

One traditional view of regional trade agreements is that starting from an initial tariff equilibrium, one could view customs unions as an intermediate step or "stepping stone" on the path to free trade. In the context of our model, this means that starting at Nash equilibrium two countries could benefit from forming a customs union (and would presumably do so) and starting from the customs union equilibrium all countries would do better at free trade (and would presumably move to free trade.) In this context, customs unions facilitate the attainment of free trade by providing a path along which countries gain each step of the way until free trade is obtained. ${ }^{10}$ In our numerical analysis this combines the result that in $47 \%$ of the cases both members benefit by moving from a threecountry Nash equilibrium to a customs union with the result that in approximately $23 \%$ of these cases both member countries of a customs union also benefit from a further move to free trade. Given these numbers this suggests that the maximum probability that customs unions are a stepping stone to free trade is about $10 \%$ $(.23 \mathrm{x} .47=.1081)$. Given this is not surprising that in only about $4 \%$ cases do both circumstances hold and customs unions are a "stepping stone" to free trade. The view that customs unions are likely to be an intermediate step on the way to free trade is not supported by our results.

Results for proposition 5 suggest that in more than $70 \%$ of the cases, customs unions raise common external tariff rates relative to three-country Nash levels. Krugman (1991) shows that customs unions always increase tariffs, a proposition that is not generally true once asymmetric cases are considered. The intuition for why customs unions lower tariffs some of the time can be found in a paper by Syropoulos (1999). Here he argues that when two countries form a customs union there are two effects working against each other in determining the optimal external tariff for the union. First, there is a tariff reduction effect. As customs unions members eliminate tariffs between them the optimal external tariff falls.

\footnotetext{
${ }^{10}$ Starting at Nash equilibrium the country excluded fiom the customs union would probably be worse, but they would bo unable to stop the customs umion from forming.
} 
Second, there is a tariff increasing effect as the customs union internalizes the tariff externality that occurs when members import the same good. Thus, there are two forces working in opposite directions. This intuition suggests that customs union external tariffs fall when the tariff externality is small accounting for the results here, generally cases where the customs union members do not import much of the same good.

Results for proposition 6 suggest that customs unions improve their external terms of trade relative to Nash in a large majority of cases. Subsequent sensitivity analysis suggests that this result depends on country size, since a customs union's external terms of trade deteriorates when the customs union is small relative to the third country. This result is not surprising if one views the problem from non-member country's point of view. In Nash equilibrium they compete against two other countries that are setting their tariffs independently. When those two countries form a customs union the third country now faces what is essentially one country from the point of view of trade policy. Hence it is not surprising that the non-member's terms of trade deteriorate vis a vis the member countries.

Propositions 7 and 8 indicate the extent to which customs unions are pro-trade, in the sense that they lead to more trade among member countries. Proposition 7 shows that a quarter of time customs union countries trade more than they would at free trade. Proposition 8 results suggest that if we compare customs union to Nash equilibria nearly $87 \%$ of the time members trade increases moving to the customs union. Theory suggests that with a customs union the volume of internal trade increases while external trade falls, but provides no guidance as to which effect will dominate. These results indicate that at least compared to Nash equilibrium the increase in internal trade will usually dominate. One other effect that our computations take into account is that the volume of trade may be affected by changes in the pattern of trade, a feature that theoretical literature ignores.

\subsection{Sensitivity Analysis}

The results we report above for the various customs union cases will also produce different frequencies for different parameterization procedures. In Table 4 we report results in which the number of randomizations used to generate frequency results is varied. Our central case results in Table 2 use 2000 randomizations. Here, we report additional cases for 500, 1000 and 3000 randomizations. Results indicate minor variations in results across these different procedures. This suggests 
that the frequencies obtained using 2000 randomizations have small standard errors. 
Table 4

Sensitivity Analysis to Full Randomization Sample Frequencies

(percentage sample frequencies for which the proposition holds)

Proposition

1. Both members benefit from a customs union relative to free trade

2. Both members benefit from a customs union

relative to a $\mathrm{N}$ ash equilibrium

3. Customs union increases world welfare relative

to a 3 -country $\mathrm{Nash}$ equilibrium

4. Customs unions are a "stepping stone" to free

trade (i.e. members are better off in CU relative

to Nash, and members gain on free trade)

5. Customs union results in higher external tariffs

for member countries relative to a Nash

equilibrium

6. Customs union improves member countries'

terms of trade relative to a Nash equilibrium

7. Customs union increases member countries'

volume of trade relative to free trade

8. Customs union increases member countries'

volume of trade relative to a Nash equilibrium

Centre
Case

7
7
7

3,000

1,000

500

randomizations

randomizations

22.9

22.2

23.3

25.0

47.6

47.2

47.4

48.1

76.0

76.3

74.8

77.9

3.6

72.2

72.0

73.2

72.2

88.6

89.8

88.9

88.4

27.1

27.4

27.7

24.9

86.9

87.7

88.2

88.4 


\subsection{Grid Search versus Randomization}

In Table 5 we report results which compare grid search and randomization procedures. Because the grid search is restricted only to endowments, for the reasons of tractability noted above, we undertake a randomization analysis only over endowments using 2000 randomizations as in the central case. We also report the full randomization results from Table 3 , and a case in which randomization is restricted to preference parameters only rather than endowments.

These results show a high degree of similarity between grid search and endowment restricted randomization. There are, however, large differences between these cases and the complete randomization case. Taken together, these results suggest that the method used to generate sample frequencies may be less important than the restrictions placed on the search made, independent of the method used. In other words, it may not make much difference whether grid search or randomization is used, but inclusion of different variables appears to have an important effect on the outcome. 
Table 5

Proposition Sample Frequencies Computed Using Both

Grid Search and Randomization Techniques

(Percentage Sample Frequencies for which the Proposition Holds)

Proposition

1. Both members benefit from

a customs union relative to free trade

2. Both members benefit from a 81. customs union relative to a Nash equilibrium

3. Customs union increases world welfare relative to a 3-country Nash equilibrium

4. Customs unions are a "stepping stone" to free trade

5. Customs union results in higher external tariffs for member countries relative to a Nash equilibrium 6. Customs union improves member countries' terms of trade relative to a Nash equilibrium

7. Customs union increases member countries' volume of trade relative to free trade

8. Customs union increases member countries' volume of trade relative to a Nash equilibrium

79.5

98.5

98.2

27.1

96.24

8. 1

3.1

27.1

19.44

91.6

89.1

86.9

88.87 


\subsection{Discriminant Analysis}

We have also undertaken further analyses of our results in which we impose various conditions on them in an attempt to ascertain whether various conditions holding makes it more or less likely that particular propositions will hold. We term this discriminant analysis. Results in Table 6 show the deviation in sub-sample frequencies where propositions hold from full sample frequencies.

In the intra customs union country size cases, for example, we calculate the number of cases for which the income of country 1 exceeds that of country 2 and then determine the sample frequency for each proposition in that sub-sample. We then deduct the full sample frequency from this, giving the deviations (in percentages) of sub-sample from full sample frequencies. Numbers which are small (closer to zero) indicate that the discriminant has little impact on sample frequencies. We consider two types of discriminants in Table 6; some relating to the relative incomes of member countries in a union to capture the importance of country size within the union, and others relating to relative incomes across the union and non-union countries. We impose conditions of increasing stringency in applying these tests, and as we do so the number of cases in the larger sample meeting those restrictions falls.

The discriminant analysis for Propositions 7 and 8 provide some interesting results which taken together suggest that size inequality within the customs union make it less likely that customs unions increase trade volume, while size inequality between union and non-union members make it more likely.Consider for example, Proposition 7 which implies that in $23.8 \%$ of cases customs union increases member countries' volume of trade relative to free trade. If we then take our 2000 randomizations and select all those in which the income of country 1 exceeds the income of country 2 then that percentage of cases for which Proposition 7 holds falls by $10.1 \%$ so that for that particular sub-sample, trade volume increases in $13.7 \%$ of cases. For the case in which income of country 1 exceeds 1.5 times the income of country 2 the percentage of cases for which Proposition 7 holds falls by $15.4 \%$ meaning that it holds $12.4 \%$ of the time. Using this discriminant analysis in this way we try and get some insight into the role that relative incomes play, both internal and external to the customs union, in driving the results we have. 


\section{Table 6}

\section{Discriminant Analysis of Customs Union Proposition Frequencies*}

(Results show percentage deviation of sub-sample frequencies for propositions** from

full sample frequencies)

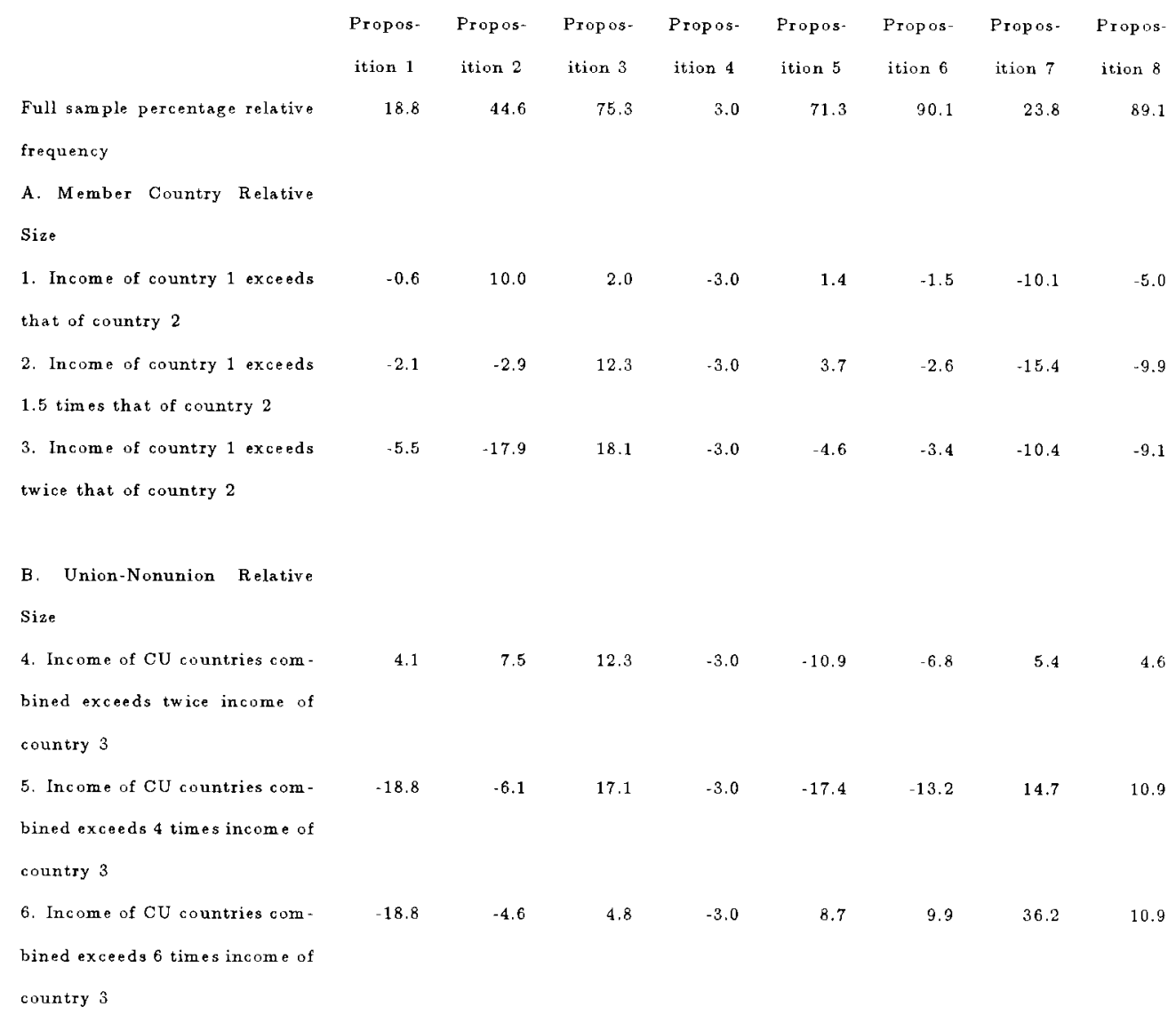

* We consider 2,000 randomization cases in generating these results

** These are

P1: CU welfare compared to FT

P2: CU welfare compared to Nash

P3: World welfare compared to Nash

P4: Stepping stone
P5: External tariff

P6: TT improvement for $\mathrm{CU}$ as a whole

P7: CU trade volume increase relative to FT

P8: CU trade volume increases relative to Nash 


\section{CONCLUSION}

In this paper we use computational methods to calculate sample frequencies for parameterizations for which various propositions in the customs union literature hold for a given model. Our motivation is that despite fifty years of research, most if not all propositions in customs union literature remain ambiguous. These include whether customs unions raise world welfare, the welfare of particular countries, tariff levels, and other variables, and for each relative proposition alternative base cases as the reference point are investigated. The usual argument made against numerical analysis is that only statements conditional on a particular numerical specification be made. Here we examine equilibria associated with different parameterizations drawn from the admissible parameter space using both randomization and grid search techniques. We use a 3-country, 3-good Cobb-Douglas/CES pure exchange economy. Our results show, for example, that for the model we consider, world welfare increases under a customs union relative to a Nash equilibrium more than $70 \%$ of the time.

Taken as a set we interpret our results as suggesting that few (or none) of the propositions we investigate are extrema; they are neither theoretical curiosa, nor largely true. Whether they hold depends on model characteristics that are amenable to investigation. Results seem robust to alternative procedures for analysis, and constraints are applied in propositional analysis to demonstrate this. Blending theory and numerical simulation thus provides useful insights as to when propositions may hold in these cases, and we suggest that this may also be so in other cases where theory does not yield unambiguous conclusions. 


\section{R eferences}

[1] Bhagwati, J. and Panagariya, (1996), "Preferential trading areas and multilateralism: stramgers. friends or foes?". In J. Bhagwati and a. Panagariya (eds), Free Trade A reas or Free Trade? The E conomics of P referential Trading Aagreements. Washington, D.C.: AEI Press.

[2] Francois, J.F., B. MacDonald and H. Nordstrom (1996), "The Uruguay Round: a numerically based qualitative assessment". In Martin, W. and A. Winters (eds), T heU ruguay Round and the Developing Countries. Cambridge, New York and Melbourne: Cambridge University Press

[3] Hamilton, R. and J. Whalley (1985), "Geographically discriminatroy trade arrangements". Review of E conomics and Statistics 67: 446-55.

[4] Harrison, G.W., T.F. Rutherford and D.G. Tarr (1996), "Quantifying the Uruguay Round" in (eds) W. Martin and L.A. Winters, The Uruguay Round and the Developing Economies, the World Bnk Discussion Paper No.307, 1995; (eds) W. Martin and L.A. Winters, The Uruguay Round and the Developing Countries, Cambridge University Press 1996; and E conomic J ournal, September 1997, Vol 107, no.44, pp.1405-1430.

[5] Kemp, M. (1969), The Pure Theory of International Trade and Investment. London: Prentice-Hall.

[6] Kemp M. and H. Wan (1976), "An elementary proposition concerning the formation of Customs Unions". J ournal of International Economics 6: 9597.

[7] Kennan, J. and R. Riezman (1990), "Optimal tariff equilibria with customs unions". Canadian J ournal of Economics 90: 70-83.

[8] Kehoe, T. (1980), "An index theorem for General Equilibrium Models with production", Econometrica 48:1211-32.

[9] Kowalczyk, C. (1989), "Trade negotiations and world welfare." American Economic Review 79: 552-59.

[10] Kowalczyk, C. (1999), "Welfare and customs unions", forthcoming in International Economic Review. 
[11] Lipsey, R. G. (1957), "The theory of customs unions: trade diversion and welfare", E conomica 24: 40:46.

[12] Lipsey, R. G. (1960), "Thetheory of customs unions: a general survey". E conomic J ournal 70:498-513.

[13] Lipsey, R. G. (1970), The theory of Customs Unions: A General Equilibrium Analysis. London: Weidenfeld and Nicholson.

[14] Lipsey, R. G. and K. Lancaster (1956), "The general theory of second best". Review of Economic Studies, 24, 11-32.

[15] Lloyd, P.J. (1982), "A 3x3 theory of customs unions". J ournal of International E conomics 12: 41-63.

[16] Meade, J.E. (1955), The Theory of Customs Unions. Amsterdam: NorthHolland.

[17] Miller, M.H. and Spencer, J.E. (1971), "The static economic effects of the UK joining the EEC: a General Equilibrium approach". Review of E conomic Studies 44:71-93.

[18] Perroni, C. and J. Whalley (2000), "The new regionalism: trade liberalization or insurance?". Canadian J ournal of Economics 33:

[19] Perroni, C. and J. Whalley (1996), "How severe is global retaliation risk under increasing regionalism?". American Economic Review 86:57-61.

[20] Riezman, R. (1979), "A 3x3 model of customs unions". J ournal of International E conomics 9: 341-354.

[21] Riezman, R. (1985), "Customs unions and the core"". J ournal of International Economics 19: 355-365.

[22] Riezman, R. (1999), "Can bilateral agreements hel induce free trade?". Canadian J ournal of E conomics 32: 751-766.

[23] Shoven, J.B. and J. Whalley (1974). "On the computation of competitive equilibrium on international markets with tariffs". J ournal of International E conomics 4: 341-354. 
[24] Summers, L. (1991), "Regionalism and the world trading system". Federal Reserve Bank of Kansas City (Policy Implications of Trade and Currency Zones), 295-301.

[25] Syriopoulos, C. (1999), "Customs unions and comparative advantage". Oxford E conomic Papers 51: 239-266.

[26] Viner, J. (1950), The Customs Union I ssue. New York: Carnegie Endowment for International Peace.

[27] Whalley, J. (1985), Trade Liberalization A mong Major W orld Trading A reas. Cambridge, Mass. London: MIT Press.

[28] Wooton, I. (1986), "Preferential trading agreements: an investigation". J ournal of International Economics 21: 81-97. 